\title{
Tingkat Pengetahuan Erosi Gigi pada Mahasiswa Profesi di Rumah Sakit Gigi dan Mulut Jakarta
}

\section{The Level of Knowledge on Tooth Erosion Among Dental Students in Dental Hospital, Jakarta}

\author{
Alisa Novianty Pratiwi, Okky Marita Ardy \\ Faculty of Dentistry, YARSI University, Jakarta \\ Jalan Letjen Suprapto, Cempaka Putih, Jakarta 10510 \\ Correspondent Email: alisa.novianty@yarsi.ac.id
}

KATA KUNCI Erosi Gigi, Pelajar Gigi, Pengetahuan

ABSTRAK Desain penelitian ini adalah penelitian cross-sectional, dengan tujuan untuk menilai pengetahuan yang berkaitan dengan erosi gigi diantara mahasiswa profesi kedokteran gigi yang bekerja di rumah sakit gigi dan mulut, Jakarta. Data dikumpulkan dengan menggunakan kuesioner yang didistribusikan kepada 90 peserta dari tiga rumah sakit gigi dan mulut di Jakarta. Tingkat respon peserta adalah 100\%. Uji Chi-square dan Mann-Whitney digunakan untuk menganalisis variabel penelitian $(\mathrm{p}<0,05)$. Mayoritas peserta telah mendengar tentang erosi $(95,6 \%)$. $33,3 \%$ dari responden hampir tidak melihat pasien dengan erosi gigi, dan $37,8 \%$ melaporkan mereka melihat pasien yang mengalami erosi gigi dalam sebulan di rumah sakit gigi dan mulut, tempat mereka bekerja. $90 \%$ responden mengetahui dan merasa dapat melakukan diagnosa kondisi erosi gigi.

\section{KEYWORDS Tooth Erosion, Dental Student, Knowledge}

ABSTRACT The aim of this cross-sectional study was to assess knowledge related to tooth erosion among dental students in dental hospital, Jakarta. Data were collected by means of a self-applied questionnaires that were distributed among 90 participants from three dental hospitals in Jakarta. The response rate was 100 percent. Chi-square and MannWhitney tests were used for statistical analysis $(p<0.05)$. The majority of the participants had heard about erosion (95.6 percent). 33.3 percent of the students almost had not seen a patient with erosion, and 37.8 percent reported they saw a patient with erosion in a month at their dental hospital. 90 percent of the students were knowledgeable and well-prepared to diagnose the condition. 


\section{PENDAHULUAN}

Erosi gigi bukanlah lesi baru dalam dunia kedokteran gigi. Sebuah survei epidemiologi di Hong Kong menyatakan bahwa $75 \%$ anak usia 12 tahun mengalami erosi gigi (Zhang et al., 2014), dan di negara Libya, terdapat $40,8 \%$ anak usia 12 tahun yang mengalami erosi gigi (Huew et al., 2012). Pada negara Yunani terdapat $78,8 \%$ anakanak usia 5 tahun yang memiliki gigi yang erosi (Montananaki, 2013). Pada kota Jakarta, Indonesia prevalensi erosi gigi pada anak usia 12 tahun sebesar 88\% (Septalita et al., 2017), dan 23,3\% anak usia 5 tahun telah memiliki erosi gigi (Maharani et al., 2019).

Erosi gigi adalah kerusakan jaringan keras gigi yang bersifat progresif dan irreversible, terjadi oleh karena proses kimia tanpa melibatkan aktifitas bakteri. Pada erosi gigi terjadi proses demineralisasi email oleh asam, namun bukan berasal dari asam hasil metabolisme bakteri (Lussi, 2006; Ren, 2011). Telah diketahui bahwa erosi gigi disebabkan oleh paparan asam tanpa melibatkan aktifitas bakteri. Asam ini dapat berasal dari dalam tubuh (faktor intrinsik) dan luar tubuh (faktor ekstrinsik). Asam intrinsik pada erosi gigi dapat disebabkan oleh asam yang berasal dari gangguan pencernaan seperti pada penderita gastroesophageal reflux disease (GERD), bulimia, anoreksia dan penyakit lainnya yang disebabkan oleh produksi asam yang berlebih. Asam ekstrinsik erosi gigi adalah asam yang didapatkan karena mengonsumsi makanan dan minuman yang mengandung asam ( $\mathrm{pH}$ rendah), dan dapat pula berasal dari paparan uap asam yang ada di lingkungan masyarakat. (Lussi, 2006; Ren, 2011).

Gejala awal erosi gigi dapat terlihat pada lapisan email yang terkikis, dan bila terus berkembang dapat mencapai lapisan dentin, dan ruang pulpa. Kehilangan struktur gigi ini dapat menyebabkan fraktur email yang mengurangi nilai estetik, serta dapat menyebabkan berkurangnya dimensi vertikal dari oklusal gigi, sehingga dapat mengganggu pengunyahan. Pada tahap lebih lanjut dapat menimbulkan rasa sakit berupa gejala hipersensitif dentin, dan inflamasi pulpa. (Lussi, 2006; Ren, 2011; Tao, 2015).

Penyebab erosi gigi yang multifaktorial, dan keadaan erosi gigi tahap awal yang sulit didiagnosa, merupakan salah satu alasan tingkat kesadaran erosi gigi rendah di masyarakat maupun di kalangan tenaga kesehatan gigi (Chu, 2010). Kebanyakan orang tidak akan mencari perawatan untuk erosi gigi sampai lesi ini mencapai tahap lanjut yang menimbulkan gejala hipersensitif, dan membutuhkan perawatan restoratif(Lussi, 2006). Sebagai langkah preventif dari erosi gigi, maka dokter gigi harus mampu mengidentifikasi erosi gigi sejak tahap awal, memahami faktor risiko yang menyebabkan erosi gigi pada setiap pasien, dan melakukan perawatan preventif maupun kuratif yang diperlukan.

Kemampuan melakukan diagnosa erosi gigi pada tahap awal sangat tergantung pada kemampun dokter gigi untuk mendeteksi gambaran klinis erosi gigi, namun demikian, belum ada penelitian adekuat yang dapat memberi gambaran tingkat pengetahuan mengenai erosi gigi di kalangan tenaga kesehatan gigi, khususnya di Jakarta.

Mahasiswa fakultas kedokteran gigi tingkat profesi yang telah melakukan kegiatan praktik di rumah sakit gigi dan mulut Jakarta, merupakan calon dokter gigi yang memegang peranan penting untuk meningkatkan kesehatan masyarakat di masa yang akan datang. Berdasarkan hal tersebut, maka sangat penting untuk mendapatkan data me- 
mengenai tingkat kesadaran dan pengetahuan erosi gigi pada mahasiswa tingkat profesi kedokteran gigi.

\section{METODOLOGI}

Jenis penelitian ini adalah penelitian cross-sectional, yang dilaksanakan dalam periode Oktober 2018 hingga Maret 2019 di tiga RSGM Jakarta. Subyek penelitian adalah mahasiswa tingkat profesi yang bekerja di RSGM Universitas YARSI, RSGM Universitas Indonesia, dan RSGM Universitas Trisakti.

Penelitian ini Menggunakan kuesioner yang terlebih dahulu telah dilakukan validasi. Tahapan pertama adalah adapatasi kuesioner dari peneitian terdahulu untuk populasi DKI Jakarta berdasarkan Expert Opinion. Tahapan berikutnya melakukan translation, back translation, review dan penilaian dari ahli yang memiliki kemampuan bilingual (Inggris dan Indonesia), dan kemudian hasilnya dilakukan pretesting pada 25 orang (convenience sample). Instrumen yang digunakan sudah dalam bahasa Indonesia. Reliabilitas kuesioner diukur dengan Cronbach $\mathrm{s}$ alpha, dengan koefisien 0,72 yang mengindikasikan dapat diterima.

Kuesioner berisi beberapa bagian yaitu 9 pertanyaan terbuka mengenai informasi demografi responden, dan 16 pertanyaan tertutup mengenai pengetahuan responden terhadap erosi gigi, dan penilaian diri sendiri atas pengetahuan serta kemampuannya dalam menegakkan diagnosa erosi gigi.

Kuesioner didistribuikan kepada responden dan diisi sendiri oleh responden. Responden yang tidak mengisi secara lengkap kuesioner, maka dianggap gugur.

Jenis data pada penelitian ini adalah data primer. Data dianalisis dengan menggunakan program SPSS versi 20 dengan uji deskriptif untuk menilai frekuensi jawaban setiap pertanyaan pada kuesioner. Analisis chi square dan mannwhitney dilakukan untuk menilai perbedaan berdasarkan variabel jenis kelamin, asal RSGM tempat responden bekerja, tahun masuk program sarjana kedokteran gigi (SKG), tahun masuk program profesi kedokteran gigi (pDRG), serta lama responden bekerja di RSGM dengan tingkat pengetahuan erosi gigi. Batas kemaknaan yang digunakan adalah 0,05 (p. value $<0.05$ ).

\section{ISI}

Penelitian ini telah disetujui oleh komite etik berdasarkan surat kelayakan etik No.292/KEP-UY/BIA/XI/2018, dan pengambilan data penelitian dilakukan mulai Januari hingga Februari 2019. Jumlah responden yang diperiksa dalam penelitian ini adalah 90 mahasiswa tingkat profesi yang bekerja di tiga Rumah Sakit Gigi dan Mulut (RSGM) di Jakarta, yaitu RSGM Universitas YARSI, RSGM Universitas Indonesia, dan RSGM Universitas Trisakti. Seluruh 90 responden tersebut telah setuju mengikuti penelitian, dan melengkapi kuesioner yang dibagikan. Berdasarkan ini respone rate penelitian ini sebesar $100 \%$.

Distribusi responden pada penelitian ini adalah, 30 mahasiswa yang bekerja di RSGM Universitas YARSI, 30 mahasiswa yang bekerja RSGM Universitas Indonesia, dan 30 mahasiswa yang bekerja di RSGM Universitas Trisakti (Tabel 1). Responden adalah ma- 
hasiswa yang memulai studi kedokteran gigi sejak 2012, 2013, dan 2014, dan memulai program profesi di RSGM sejak 2016, 2017, dan 2018, artinya terdapat mahasiswa yang baru memulai program profesi selama 1 semester hingga 6 semester.

Responden penelitian menjawab 16 pertanyaan yang berkaitan dengan erosi gigi, 12 pertanyaan akan menggambarkan tingkat pengetahuan erosi gigi, 4 pertanyaan lainnya mengenai kesadaran mereka akan tingkat pengetahuan dan kemampuannya dalam mendiagnosa erosi gigi, serta sumber informasi pertama mereka mengetahui mengenai erosi gigi. Berdasarkan dari 12 pertanyaan tingkat pengetahuan, kemudian dikelompokan menjadi tiga tingkat pengetahuan mengenai erosi gigi, yaitu rendah, sedang, tinggi. Maka didapatkan bahwa $2(2.2 \%)$ responden memiliki pengetahuan yang rendah, 32 (35.6\%) responden memiliki pengetahuan erosi gigi yang sedang dan $56(62.2 \%)$ reponden memiliki tingkat pengetahuan yang tinggi (Tabel 2).

Melalui pertanyaan mengenai kesadaran mereka akan tingkat pengetahuan mengenai erosi gigi, didapatkan bahwa 44 (48.9\%) merasa bahwa memiliki pengetahuan yang sangat baik, dan $46 \quad(51.1 \%)$ merasa pengetahuannya kurang baik mengenai erosi gigi. Berdasarkan kesadaran mereka mengenai kemampuan dalam mendiagnosa dan melakukan perawatan erosi gigi, 81 (90\%) responden merasa mampu melakukannya, dan hanya 9 (10\%) merasa belum mampu.

Peneliti juga menanyakan frekuensi responden melihat kasus erosi gigi pada pasien RSGM tempat mereka bekerja, dan dinyatakan bahwa $4(4.4 \%)$ repsonden melihat kasus tersebut setiap hari, 8 (8.9\%) seminggu sekali, $34 \quad(37.8 \%)$ sebulan sekali, 14 (15.6\%) setahun sekali, dan $30(33.3 \%)$ responden tidak pernah melihat kasus erosi gigi selama bekerja di RSGM.

Tabel 1. Distribusi responden penelitian berdasarkan RSGM tempat bekerja, dan jenis kelamin

\begin{tabular}{l|cc|c}
\hline \multicolumn{1}{c}{ RSGM } & $\begin{array}{c}\text { Laki-Laki } \\
\mathrm{n}(\%)\end{array}$ & $\begin{array}{c}\text { Perempuan } \\
\mathrm{n}(\%)\end{array}$ & \multicolumn{1}{c}{ Total } \\
\hline Universitas YARSI & $2(22.2 \%)$ & $8(34.6 \%)$ & $30(100 \%)$ \\
Universitas Indonesia & $3(33.3 \%)$ & $27(33.3 \%)$ & $30(100 \%)$ \\
Universitas Trisakti & $4(44.4 \%)$ & $26(32.1 \%)$ & $30(100 \%)$ \\
\hline Total & $9(100 \%)$ & $81(100 \%)$ & $90(100 \%)$ \\
\hline
\end{tabular}

Tabel 2. Distribusi responden penelitian berdasarkan tingkat kesadaran dan pengetahuan erosi gigi

\begin{tabular}{l|cc|c|c}
\hline \multicolumn{1}{c}{ RSGM } & \multicolumn{2}{c}{ Tingkat kesadaran dan pengetahuan erosi gigi } & \multirow{2}{*}{ Total } \\
& Rendah & Sedang & Tinggi & \\
\multicolumn{1}{c}{} & & & \\
\hline Universitas YARSI & $0(0)$ & $14(46.7 \%)$ & $16(53.3 \%)$ & $30(100 \%)$ \\
Universitas Indonesia & $2(6.7 \%)$ & $9(30 \%)$ & $19(63.3 \%)$ & $30(100 \%)$ \\
Universitas Trisakti & $0(0)$ & $9(30 \%)$ & $21(70 \%)$ & $30(100 \%)$ \\
\hline Total & $2(2.2 \%)$ & $32(35.6 \%)$ & $56(62.2 \%)$ & $90(100 \%)$ \\
\hline
\end{tabular}


Pada penelitian ini, responden juga ditanyakan mengenai sumber informasi pertama kali mereka mendengar mengenai erosi gigi, dan didapatkan bahwa $86(95.6 \%)$ mendengar informasi erosi gigi pada saat menjalankan program sarjana kedokteran gigi, 1 (1.1\%) pada saat program profesi kedokteran gigi, 1(1.1\%) melalui seminar, dan 2 (2.2.\%) melalui media informasi lainnya, seperti buku, jurnal, atau video pengetahuan.

Analisa lebih mendalam dilakukan melalui uji statitisk chi square dan uji mann-whitney untuk mendapakan perbedaan hubungan antara tingkat kesadaran dan pengetahuan dengan jenis kelamin, RSGM tempat responden bekerja, tahun masuk program sarajana kedokeran gigi, tahun masuk program profesi kedokteran gigi dan lama mereka bekerja di RSGM (semester). Berdasarkan hasil uji tersebut, didapatkan bahwa hanya jenis kelamin yang memiliki perbedaan bermakna dengan tingkat kesadaran dan pengetahuan erosi gigi, dengan hasil $p$ value $<0,05$ (Tabel 3).

Tabel 3. Analisis perbedaan tingkat pengetahuan erosi gigi pada mahasiswa profesi yang bekerja di RSGM Jakarta

\begin{tabular}{|c|c|c|c|c|c|}
\hline & \multicolumn{3}{|c|}{ Tingkat Pengetahun } & \multirow{2}{*}{$\begin{array}{l}\text { Total } \\
\text { n (\%) }\end{array}$} & \multirow[t]{2}{*}{ P-Value } \\
\hline & $\begin{array}{c}\text { Rendah } \\
\mathrm{n}(\%)\end{array}$ & $\begin{array}{c}\text { Sedang } \\
\mathrm{n}(\%)\end{array}$ & $\begin{array}{l}\text { Tinggi } \\
\mathrm{n}(\%)\end{array}$ & & \\
\hline \multicolumn{6}{|l|}{ Jenis Kelamin } \\
\hline Laki - laki & $0(0)$ & $0(0)$ & $9(100 \%)$ & $9(100 \%)$ & $0,048 *$ \\
\hline Perempuan & $2(2.5 \%)$ & $32(39.5 \%)$ & $47(58 \%)$ & $81(100 \%)$ & \\
\hline \multicolumn{6}{|l|}{ RSGM } \\
\hline Universitas YARSI & $0(0)$ & $14(46.7 \%)$ & $16(53.3 \%)$ & $30(100 \%)$ & 0.182 \\
\hline Universitas Indonesia & $2(6.7 \%)$ & $9(30 \%)$ & $19(63.3 \%)$ & $30(100 \%)$ & \\
\hline Universitas Trisakti & $0(0)$ & $9(30 \%)$ & $21(70 \%)$ & $30(100 \%)$ & \\
\hline \multicolumn{6}{|l|}{ Tahun masuk SKG } \\
\hline 2012 & $0(0)$ & $4(44.4 \%)$ & $5(55.6 \%)$ & $9(100 \%)$ & 0.542 \\
\hline 2013 & $1(1.8 \%)$ & $17(29.8 \%)$ & $39(68.4 \%)$ & $57(100 \%)$ & \\
\hline 2014 & $1(4.2 \%)$ & $11(45.8 \%)$ & $12(50 \%)$ & $24(100 \%)$ & \\
\hline \multicolumn{6}{|l|}{ Tahun masuk pDRG } \\
\hline 2016 & $0(0)$ & $4(44.4 \%)$ & $5(55.6 \%)$ & $9(100 \%)$ & 0.542 \\
\hline 2017 & $1(1.8 \%)$ & $17(29.8 \%)$ & $39(68.4 \%)$ & $57(100 \%)$ & \\
\hline 2018 & $1(4.2 \%)$ & $11(45.8 \%)$ & $12(50 \%)$ & $24(100 \%)$ & \\
\hline \multicolumn{6}{|l|}{ Jumlah Semester pDRG } \\
\hline 1 & $0(0)$ & $2(50 \%)$ & $2(50 \%)$ & $4(100 \%)$ & 0.950 \\
\hline 2 & $1(5 \%)$ & $9(45 \%)$ & $10(50 \%)$ & $20(100 \%)$ & \\
\hline 3 & $0(0)$ & $4(36.4 \%)$ & $7(63.3 \%)$ & $11(100 \%)$ & \\
\hline 4 & $1(2.2 \%)$ & $13(28.3 \%)$ & $32(69.6 \%)$ & $46(100 \%)$ & \\
\hline 5 & $0(0)$ & $1(50 \%)$ & $1(50 \%)$ & $2(100 \%)$ & \\
\hline 6 & $0(0)$ & $3(42.9 \%)$ & $4(57 . \%)$ & $7(100 \%)$ & \\
\hline
\end{tabular}


Penelitian ini menyatakan bahwa erosi gigi bukanlah hal baru lagi bagi para mahasiswa yang bekerja di tiga RSGM kawasan Jakarta. 95.6\% dari repsonden telah mengetahui erosi gigi bahkan sejak mereka menempuh program sarjana kedokteran gigi, dan $90 \%$ diantaranya merasa mampu dalam mendiagnosa dan melakukan perawatan erosi gigi. Hal ini juga didukung dengan hasil penelitian yang menyatakan bahwa $62.2 \%$ diantara mereka memiliki tingkat kesadaran dan pengetahuan erosi gigi yang tinggi, serta $35.6 \%$ memiliki tingkat yang sedang. Namun demikian, berdasarkan jawaban responden $37.8 \%$ hanya melihat kasus erosi gigi sekitar sebulan sekali, dan $33.3 \%$ hampir tidak pernah melihat kasus tersebut. Hal ini bertolak belakang dengan penelitian yang dilakukan oleh Maharani dkk., yang menyatakan bahwa kasus erosi gigi di DKI Jakarta sudah terlihat sejak usia 5 tahun, dan prevalensinya meningkat terus seiring bertambah usia (Maharani et al., 2019). Penelitian lain dari Septalita dkk. menyatakan bahwa $88 \%$ anak usia 12 tahun di Jakarta telah mengalami erosi gigi, dan prevalensi juga meningkat seiring bertambah usia (Septalita et al., 2017). Berdasarkan dua penelitian ini, dapat diasumsikan bahwa kasus erosi gigi akan mudah ditemukan pada pasien di RSGM. Hal ini mungkin terjadi karena, pasien yang datang ke RSGM memiliki kasus kesehatan gigi lain seperti kalkulus yang mencapai permukaan oklusal/incisal, karies gigi tahap lanjut, dan kehilangan gigi, sehingga gigi yang berisiko terkena erosi gigi telah lebih dulu terkena penyakit lainnya. Mendiagnosa erosi gigi secara klinis pada tahapan awal banyak dianggab sulit, bahkan oleh para ahli. Hal ini juga dapat menjadi alasan mengapa erosi gigi jarang terlihat pada pasien di RSGM (Lussi, 2006; Zhang et al.,2014)
Berbagai penelitian belakangan ini, telah banyak membuktikan bahwa prevalensi erosi gigi telah meningkat di berbagi negara, dan di berbagai kelompok usia. Informasi ini telah diketahui oleh $53.3 \%$ responden, dan terdapat $38.9 \%$ yang menjawab tidak tahu, $4.4 \%$ menjawab tidak berubah, $3.3 \%$ menjawab prevalensi menurun. Hal ini berarti walaupun tingkat pengetahuan erosi gigi baik, namun terdapat $46.6 \%$ repsonden yang tidak menyadari bahwa erosi gigi kini menjadi salah satu lesi yang menjadi perhatian di kalangan ahli kesehatan gigi karena telah terjadi peningkatan prevalensi di masyarakat. Erosi gigi juga dikhawatirkan menjadi beban kesehatan, karena erosi gigi dapat memberikan dampak, seperti menurunnya estetik, dentin hipersensitif, dan menurunkan kemampuan mengunyah, sehingga dapat mengurangi kualitas hidup seseorang. Selain itu, perawatannya membutuhkan perawatan yang kompleks sehingga biayanya tinggi.

Responden penelitian ini ada yang telah bekerja di RSGM selama 1 semester sampai 6 semester. Responden yang telah bekerja selama 4 semester memiliki tingkat pengetahuan erosi gigi yang lebih baik, karena $69.6 \%$ diantaranya memiliki tingkat kesadaran dan pengetahuan erosi gigi yang tinggi. Hal ini sesuai dengan asumsi peneliti, karena umumnya masa kerja di RSGM adalah 4 semester, sehingga mahasiswa yang telah mencapai masa studi tersebut memiliki tingkat pengetahuan dan pengalaman yang lebih baik, diikuti dengan mahasiswa profesi yang telah menempuh 5 dan 6 semester.

Berdasarkan analisa ditribusi jawaban dari 12 pertanyaan mengenai erosi gigi, mayoritas responden dapat menjawab dengan benar mengenai penye- 
bab, pencegahan, pemeriksaan dan perawatan erosi gigi, namun hanya $44.4 \%$ yang dapat menjawab dengan benar faktor risiko penyebab erosi gigi. 55.6\% lainnya menjawab dengan tidak benar, dan $46.7 \%$ diantaranya menganggab bahwa hanya faktor kimia seperti $\mathrm{pH}$ rongga mulut, dan kapasitas buffer saliva yang menjadi faktor risiko erosi gigi.

Erosi gigi tidak terjadi hanya karena adanya faktor etiologi (asam). Terdapat faktor lain yang dapat meningkatkan risiko terjadinya erosi gigi. Faktor risiko erosi gigi, diantaranya adalah faktor biologis seperti saliva, acquired dental pellicle, struktur dan posisi gigi yang berkaitan dengan jaringan lunak dan lidah. Faktor risiko lainnya adalah faktor kimia yang terdiri dari $\mathrm{pH}$ dan jenis asam, kapasitas buffer, adhesi dan ions $\mathrm{Ca}, \mathrm{P}$, dan F. Faktor perilaku juga dapat menjadi faktor risiko. Perilaku diet asam, perilaku dalam menjaga kebersihan gigi dan mulut, serta kebiasaan muntah. Faktor sosial-ekonomi, pendidikan, pengetahuan, dan kesehatan umum juga merupakan faktor-faktor yang mempengaruhi terjadinya erosi gigi. Faktor-faktor tersebut akan saling berinteraksi. Hasil dari interaksi tersebut dapat menimbulkan efek risiko, atau dapat pula menimbulkan efek proteksi terhadap erosi gigi. Interakasi yang saling mempengaruhi inilah yang menyebabkan terdapat orang yang lebih berisiko terkena erosi gigi dibandingkan orang lain (Meurmann et al., 1996; Magalhaes et al., 2006; Lussi, 2006; Ren, 2011). Berdasarkan hal ini, sangat penting bagi para praktisi kesehatan gigi untuk memahami faktor risiko erosi gigi, bukan saja mengetahui etiologinya.

Mahasiswa kedokteran gigi di Indonesia, khususnya di Jakarta umumnya memiliki perbandingan jenis kelamin yang tidak seimbang. Jumlah mahasiswa perempuan selalu lebih banyak daripada mahasiswa laki-laki. Hal ini cukup mempersulit peneliti untuk mendapatkan perbandingan responden yang berimbang, sehingga jumlah repsonden perempuan lebih banyak daripada responden lakilaki. Variabel jenis kelamin memiliki perbedan bermakna terhadap tingkat kesadaran dan pengetahuan erosi gigi. Hal ini bertolak belakang pada penelitian terdahulu oleh Al-Ashtal dkk., yang tidak menemukan hubungan antara jenis kelamin dan tingkat pengetahuan erosi gigi (Al-Ashtal et al., 2015).

Perbedaan yang jauh antara jumlah responden laki-laki dan perempuan dapat menjadi kekurangan dalam penelitian ini, sehingga hasilnya dapat menjadi bias. Namun demikian, penelitian ini adalah penelitian pertama yang menganalisa tingkat pengetahuan erosi gigi di kalangan praktisi kesehatan gigi di Jakarta. Hasil penelitian yang didapatkan dapat menjadi gambaran awal tingkat kesadaran dan pengetahuan erosi gigi, dan menjadi dasar penelitian selanjutnya mengenai erosi gigi.

\section{PENUTUP}

Erosi gigi merupakan lesi yang sudah diketahui oleh mahasiswa program profesi yang bekerja di RSGM wilayah Jakarta. Mayoritas responden mengetahui etiologi, gambaran klinis, cara pencegahan, pemeriksaan, dan perawatan yang tepat untuk kasus ini. Erosi gigi adalah lesi multifaktorial, yang sulit didiagnosa pada tahap awal, dan bila telah mencapai tahap lanjut, maka membutuhkan perawatan yang kompleks dengan biaya yang cukup mahal. Berdasarkan hal tersebut, prevalensi erosi 
gigi harus segera dikendalikan, salah satunya dengan memastikan tingkat pengetahuan tenaga kesehatan gigi telah baik.

\section{DAFTAR PUSTAKA}

Al-Ashtal Amin, Johansson Anders, Omar Ridwaan, Johansson Ann-Katrin. 2015. Awareness and knowledge of dental erosion among Yemeni dental professional and students. BMC Oral Health. Volume 15, pp 119-126.

Chu C.H., Pang K.K.L., Lo E.C.M. 2010. Dietary behavior and knowledge of dental erosion among Chinese adults. BMC Oral Health. Volume 10, pp 13-19.

Huew, R., Waterhouse, P., Moynihan, P.J., Kometa, S., Maguire, A.2012. Dental caries and its association with diet and dental erosion in Libyan schoolchildren. Int $\mathrm{J}$ Pediatry Dentistry. Volume 22, No.1, pp 68-76.

Lussi A, Jaeggi T. 2008. Erosion diagnosis and risk factors. Clinical Oral Invest. Volume 12, No. 1, pp 513

Magalhaes A.C., Wiegand A, Rios D.2009. Insight Into Preventive Measures for Dental Erosion. J Appl Oral Science. Volume 17, No.2, pp 75-86.

Maharani D.A., Pratiwi A.N., Setiawati F., Zhang S., Gao S.S., Chu C.H. et al. 2019. Tooth wear among fiveyear-old children in Jakarta,
Indonesia. BMC Oral Health. Volume 19, No.1, pp 192-198.

Meurmann J.H., Cate J.M. 1996. Pathogenesis and modifying factors of dental erosion. Europe Journal Science. Volume 104, pp 199-206.

Montananaki M, Kounaro H.K., Homata EM, Papaioannou W.2013.Dental erosion prevalence and associated risk indicators among preschool children in Athens, Greece. Clinical Oral invest. Volume 17, pp 585-593.

Ren, YF. 2011. Dental Erosion: Etiology, Diagnosis and Prevention. American Dentistry. pp75-85. https://www.rdhmag.com/patietcare/article/16406331/dentalerosion-etiology-diagnosis-andprevention (Diakses 09 September 2019).

Septalita A., Bahar A., Agustanti A., Rahardjo A., Maharani DA., Rosalien R. 2017. Dental Erosion in 12-year-old school living in Jakarta. Journal of Physics: Conference Series https://iopscience.iop.org/article/10 .1088/1742-6596/884/1/012040. (Diakses 09 September 2019).

Tao, D.Y., Hao, G., Lu, H.X., Tian, Y., Feng, X.P. 2015. Dental erosion among children aged 3-6 years and its associated indicators. J Public Health Dentistry. Volume 75, No.4, pp 291-297.

Zhang, S. Chau A.M.H., Lo E.C.M., Chu C.H.2014. Dental caries and erosion status of 12-year-old Hong Kong children. BMC Public Health. Volume 14, pp 1-7. 